\title{
THE IMPACT OF ELECTRONIC DEVICES ON THE PHYSICAL GROWTH AND DEVELOPMENT OF THE MODERN YOUTH AND RECOMMENDATIONS ON THEIR SAFE USE
}

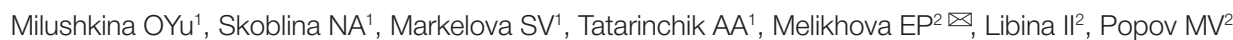

${ }^{1}$ Pirogov Russian National Research Medical University, Moscow, Russia

2 Burdenko Voronezh State Medical University, Voronezh, Russia

\begin{abstract}
The impact of excessive exposure to electronic devices (ED) on youth health remains understudied. There is a pressing need to develop recommendations for the safe use of stationary and mobile ED aimed at minimizing health risks. In this work, we assess the effect of ED on the physical growth and development of highschool and university students and provide recommendations for preventing the negative impact of prolonged screen time on health. The study recruited 460 highschool and 598 university students. Standard anthropometric measurements were taken. The psychological and emotional state of the participants was evaluated using the Test Anxiety Inventory by Spielberg (modified by Khanin). To estimate daily and weekly exposure to ED the participants were asked to fill out standardized questionnaires. In high school students, the average screen time was $7 \mathrm{~h}$ a day; in university students, 8.5 to $10 \mathrm{~h}$ a day. Only $60 \%$ of the participants, regardless of their place of residence or the type of educational institution they were attending, were physically healthy. We conclude that prolonged and frequent exposure to ED is one of the factors that can interfere with normal physical growth and development in youth. Regular daily use of stationary ED increases the risk of developing body weight deficit by $24 \%$ and gaining excess body weight by $10 \%$. We recommend that students should eliminate computers, laptops and stationary ED from their daily activities for at least one day at the weekend and reduce total screen time to 3 hours a day.
\end{abstract}

Keywords: health, electronic devices, information and communication technologies, physical growth and development, psycho-emotional state, high-school students, university students

Author contribution: Milushkina OYu and Skoblina NA supervised the study, processed the collected data and wrote the manuscript; Markelova SV, Libina II and Popov MV collected and processed the data; Tatarinchik AA analyzed the literature, collected and processed the data; Melikhova EP collected and processed the data and edited the manuscript.

Compliance with ethical standards: the study was approved by the Ethics Committee of Pirogov Russian National Medical Research University (Protocol 159 dated November 21, 2016). Informed consent was obtained from all study participants.

$\triangle$ Correspondence should be addressed: Ekaterina P. Melikhova

Studencheskaya 10, Voronezh, 394036; katerina.2109@mail.ru

Received: 04.07.2019 Accepted: 18.07.2019 Published online: 23.07.2019

DOI: 10.24075/brsmu.2019.046

\section{ВЛИЯНИЕ ЭЛЕКТРОННЫХ УСТРОЙСТВ НА ФИЗИЧЕСКОЕ РАЗВИТИЕ СОВРЕМЕННОЙ МОЛОДЕЖИ И РЕКОМЕНДАЦИИ ПО РЕГЛАМЕНТУ ИХ ИСПОЛЬЗОВАНИЯ}

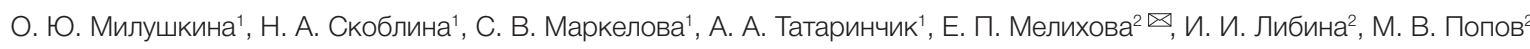

${ }_{1}^{1}$ Российский национальный исследовательский медицинский университет имени Н. И. Пирогова, Москва, Россия

2 Воронежский государственный медицинский университет имени Н. Н. Бурденко, Воронеж, Россия

\begin{abstract}
Влияние частого и длительного использования электронных устройств (ЭУ) на состояние здоровья молодежи до сих пор недостаточно изучено. Исследования по регламентации использования стационарных и мобильных Эу для обеспечения оптимального физического развития молодежи становятся особо актуальными. Целью работы было установить характер и степень влияния использования ЭУ на физическое развитие молодых людей и рекомендовать режим использования ЭУ в течение дня для профилактики возникновения отклонений в физическом развитии. Для определения физического развития 460 старшеклассников и 598 студентов использовали гигиенический, инструментальный, социологический, статистический методы исследования: стандартную антропометрическую методику; для оценки психоэмоционального состояния - тест Спилберга-Ханина; для учета использования ЭУ проводили анкетирование с применением стандартизированных опросников. При среднем суммарном ежедневном времени использования ЭУ у старших школьников, составляющем 7 ч, и у студентов, равном 8,5-10 ч, нормальное физическое развитие выявлено в среднем только у 60\% обследованных, причем это не связано с регионом проживания или типом образовательного учреждения. Показано, что частое и длительное использование ЭУ молодежью служит одним из факторов, способных вызвать отклонения в физическом развитии. Установлено, что ежедневное использование стационарных ЭУ увеличивает риск возникновения у подрастающего поколения нарушений в физическом развитии за счет десицита массы тела на 24\% и его избытка на 10\%. В качестве профилактических мероприятий рекомендованы отказ от использования стационарных ЭУ, компьютера и ноутбука на 1 день в неделю (в выходной день) и ограничение суммарного времени использования всех видов Эу до 3 ч в день.
\end{abstract}

Ключевые слова: здоровье, электронные устройства, физическое развитие, информационно-коммуникационные технологии, психоэмоциональное состояние, школьники, студенты

Информация о вкладе авторов: О. Ю. Милушкина и Н. А. Скоблина - научное руководство, обработка материала, написание статьи; С. В. Маркелова, И. И. Либина и М. В. Попов - сбор и обработка материала; А. А. Татаринчик - анализ литературных данных, сбор и обработка материала; Е. П. Мелихова - сбор и обработка материала, редактирование статьи.

Соблюдение этических стандартов: исследование одобрено этическим комитетом ФГБОУ ВО РНИМУ имени Н. И. Пирогова Минздрава России (протокол № 159 от 21 ноября 2016 г.); для каждого обследованного было получено добровольное информирование согласие.

$\triangle$ Для корреспонденции: Екатерина Петровна Мелихова

ул. Студенческая, д. 10, г. Воронеж, 394036; katerina.2109@mail.ru

Статья получена: 04.07.2019 Статья принята к печати: 18.07.2019 Опубликована онлайн: 23.07.2019

DOI: $10.24075 /$ vrgmu.2019.046

In recent years, information and communication technologies (ICT) and in particular electronic devices (ED) have been increasingly recognized as a significant environmental factor affecting young people's health [1-8]. 
Over the last two decades, ED have been actively used both inside and outside the classroom. In 2008, only 3 quarters of adolescents and young adults aged 12 to 24 years had access to Internet; by 2018 , the figures had soared to $96.9 \%$. There are now significantly more Web users who go online every day among young people than among adults. The growing size of young Internet audience can be linked to the availability of mobile ED capable of connecting to the Web, such as mobile phones in the first place $[9,10]$.

The use of ICT in the classroom is beneficial for both the teacher and the student. Although ICT deployment may not be cheap, the ultimate education costs will be lower in comparison with "traditional" education. The curriculum can be adjusted to an individual student's rate of learning based on his/her academic progress. There are no strict requirements on the learning/teaching space. ICT provide effective tools for monitoring a student's progress. In turn, any student can easily access any snippet of information taught during the course. These ICT advantages provide a possibility for inclusive learning. Still, some authors hold the opinion that expansion of computerized education significantly increases health risks for the students learning in a digital environment [11].

Overuse of ED has a number of negative effects, including escapism from the real world into the Web, deterioration of physical and mental health, etc. [12-15]. For example, research conducted in the educational institutions of Irkutsk demonstrated that intensive computerized learning negatively affected intellectual performance, increased anxiety and stimulated hyperactivity in children [16].

The use of electronic devices by children in preschool facilities and schools is regulated by a number of special guidelines, including Sanitary Rules and Regulations (SanPiN) 2.2.2/2.4 1340-03 (Requirements for personal computers and learning spaces), SanPiN 2.4.1.3049-13 (Safety and health requirements for the design, maintenance and operation of preschool educational facilities), SanPiN 2.4.2.2821-10 (Safety and health requirements for the learning environment in schools), recommendations on the Safety assessment of e-book readers and their use in educational institutions, etc. The majority of these guidelines regulate the use of stationary ED in educational institutions (but not outside the classroom), leaving mobile devices out of the equation. This shapes the need for developing total screen time recommendations for children and teenagers.

In 2015, the Government of the Russian Federation adopted the Children's Information Security Concept. The document highlights the importance of creating a safe information environment that would promote social adaptation, foster personal, cognitive, intellectual and physical development, protect and sustain mental health and wellbeing and stimulate a positive view of life [17]. A lot of effort has been channeled into researching the effects of ED on the mental and physical health of young people and into elaborating safety regulations on the use of ED. However, to this day the impact of ED on children's growth and physical development has not been studied. Therefore, it is important to propose screen time recommendations for young people in order to ensure their harmonious physical development, as prescribed by the Concept.

In the study presented below, we assess the effect of ED on the growth and physical development of high-school and university students and give screen time recommendations.

\section{METHODS}

The study conducted in 2017-2018 recruited 460 high-school students from Moscow region and 598 university students from Moscow, Voronezh and Arkhangelsk. The study included highschool/university students of both sexes who gave informed consent to participate. The mean age of the participants was 16 years for high-school and 20 years for university students. At this age young people can choose for themselves how much they will use ED during the day or at nighttime. Older and younger individuals were excluded from the study. Because it takes a certain time for the body size and composition to change, the impact of ED should be assessed in the context of its total duration. The age groups included in the study had a sufficiently long experience (over 10 years) of using ED.

Our multicenter study included schools with standard and advanced curricula, as well as gymnasiums (schools preparing students for university), and higher educational institutions specializing in 1) public healthcare and medical sciences, 2) mathematics and mechanics. The educational institutions were located in different climate zones.

First, we assessed the growth and physical development of high-school and university students using a conventional anthropometric method and instrumentation. Body height (cm) was measured with $0.5 \mathrm{~cm}$ precision with a standard anthropometer measuring set. Body weight was measured with $100 \mathrm{~g}$ precision using an InBody 230 analyzer (Biospace; South Korea). The obtained values were compared with regression scales available for the regions involved in the study.

Considering that body weight and height may not provide sufficient information about the effect of the studied factor on the growth and physical development of the participants, we additionally analyzed the body composition using an InBody 230 analyzer (Biospace; South Korea). This allowed us to estimate muscle mass $(\mathrm{kg})$, fat mass $(\mathrm{kg})$, and body mass index $\left(\mathrm{kg} / \mathrm{m}^{2}\right)$ and to provide weight management recommendations (the amount of weight the subject was recommended to gain or lose). Reference values returned by the analyzer corresponded to the normal ranges adopted in the Western clinical practice. BMI was compared to the values recommended by WHO (18.5-24.9).

Because different body builds are considered to be prone to developing different weight statuses, we determined the body build for each participant using a classification proposed by Shtefko and Ostrovsky and modified by Darskaya [18]. Characteristics of body types are presented in Table 1.

Table 1. Characteristics of body types

\begin{tabular}{|c|c|c|c|}
\hline Type & Characteristics & Prone to developing body weight deficit & Prone to gaining excess body weight \\
\hline $\begin{array}{c}\text { Asthenic, } \\
\text { weak }\end{array}$ & $\begin{array}{c}\text { Slender, flat-chested, lean, with weak musculature; } \\
\text { epigastric angle }<90^{\circ}\end{array}$ & Yes \\
\hline $\begin{array}{c}\text { Thoracic, } \\
\text { weak }\end{array}$ & $\begin{array}{c}\text { Slender with elliptical chest, average muscle } \\
\text { development, low fat mass; epigastric angle }<90^{\circ}\end{array}$ & Yes/no & No \\
\hline $\begin{array}{c}\text { Muscular, } \\
\text { strong }\end{array}$ & $\begin{array}{r}\text { Broad in shoulders, with symmetrical elliptical chest, } \\
\text { average or well-developed musculature, average } \\
\text { or increased fat mass; epigastric angle }=90^{\circ},\end{array}$ & Yes/no \\
\hline $\begin{array}{c}\text { Abdominal, } \\
\text { strong }\end{array}$ & $\begin{array}{c}\text { Broad, with short cone-shaped chest, average muscular } \\
\text { development, prone to fat deposition; epigastric angle } \geq 90^{\circ}\end{array}$ & No \\
\hline
\end{tabular}


Psychological and emotional states of the participants were assessed using the Spielberg-Khanin anxiety inventory [19].

In the second part of our study, we asked the participants to fill out standardized questionnaires designed at the Research Institute of Hygiene and Health Protection of Children and Adolescents (National Medical Research Center for Children's Health) [20]. The questionnaires allowed us to assess the frequency of exposure to ED, its total daily and weekly duration.

Lastly, the obtained data were processed using Statistica 10.0 (StatSoft; USA). We tested a hypothesis about the impact of frequency and duration exposure to ED on the physical health in young people. Arithmetic means, the standard error of the mean and the standard deviation were calculated. Student's t-test was applied to assess significance of differences. For continuous quantitative variables, Pearson's correlation coefficient was calculated. For discrete qualitative variables, contingency tables were built; relationship between the variables were assessed using Pearson's correlation coefficient.

Relative risks (RR) were calculated to estimate the probability of a certain outcome in the groups. Four-field contingency tables were constructed and analyzed using the online statistical calculator [21]. The 95\% Cl was also computed.

\section{RESULTS}

In the first part of our study, we measured the main growth parameters: body weight and height, which had typical age and sex-related peculiarities. No regional differences were observed between university students in terms of weight and height (Table 2). Using regional regression scales, we established that only $60.6 \pm 1.2 \%$ of high-school boys, $56.8 \pm 2.4 \%$ of male university students, $61.2 \pm 2.7 \%$ of high-school girls, and $63.3 \pm 1.5 \%$ of female university students were developing harmoniously.

BMl was $21.1 \pm 3.2 \mathrm{~kg} / \mathrm{m}^{2}$ and $20.1 \pm 3.3 \mathrm{~kg} / \mathrm{m}^{2}$ for highschool boys and girls, respectively. In the group of university students, BMl was $23.04 \pm 3.7 \mathrm{~kg} / \mathrm{m}^{2}$ and $21.28 \pm 3.5 \mathrm{~kg} / \mathrm{m}^{2}$ for males and females, respectively. According to $\mathrm{WHO}$ recommendations, the normal BMl range for the studied age group is between 18.5 and $24.9 \mathrm{~kg} / \mathrm{m}^{2}$. However, as many as $20.3 \%$ of male and $15.6 \%$ of female university students participating in the study had BMl over $25 \mathrm{~kg} / \mathrm{m}^{2}$.

Body weight deficit was observed in $24.2 \pm 1.5 \%$ of highschool boys, $30.6 \pm 2.1 \%$ of high-school girls, $10.5 \pm 1.2 \%$ of male and $21.8 \pm 2.3 \%$ of female university students. Excess weight was observed in $12.2 \pm 2.1 \%$ of high-school boys, $6.2 \pm 1.1 \%$ of high-school girls, $24.6 \pm 1.2 \%$ of male and $12.0 \pm 1.5 \%$ of female university students. The rest of the participants were obese. On the whole, high-school students were prone to developing body weight deficit whereas university students, to gaining excess weight.

The analysis of body composition revealed that unlike height, fat mass was increasing with age $(p<0.05)$ in both boys and girls. Importantly, the children were not building muscle mass, regardless of their sex. This is an alarming trend: children with body weight deficit do not develop sufficient muscle mass and, therefore, do not join the ranks of their normally growing peers. Although the total body weight was increasing with age in our participants, it was largely due to fat accumulation. Young people with excess body weight continued to accumulate more fat. Based on the analysis of body composition, high-school and university students were recommended to increase their muscle mass by an average of 2 to $4 \mathrm{~kg}$; additionally, university students were recommended to reduce their fat mass by an average of $2.5 \mathrm{~kg}$ (Table 2).

Additionally, we determined body build types of the young people included in the study. Relatively weak types (asthenic and thoracic) accounted for $40.0 \%$ of the participants, whereas relatively strong types (muscular and abdominal) made up $25.0 \%$ of the participants; the rest of the high-school students did not represent any particular build. Such distribution is normal for the general population. We found a correlation between the deviations from normal growth caused by weight deficit and the abdominal body build (Pearson's correlation coefficient was $0.72 ; p<0.005)$.

The alarming number of high-school and university students with abnormal body weight raises a question of their underlying causes and prompts investigation of ED contribution to body weight deficit and obesity.

In the second part of the study, the participants reported that they used different types of ED every day, including mobile phones, laptops, tablets, computers (ranked here in the descending order). Only $0.5 \%$ of the surveyed did not use ED. In this respect, no significant differences were observed between boys and girls, male and female university students, high-school and university students or the participants from different regions. This suggests that ED are enjoying wide popularity among young people in the general population.

Table 2. Growth parameters and body composition in high-school and university students presented as mean values $(\mathrm{M} \pm m)$

\begin{tabular}{|c|c|c|c|c|}
\hline \multirow{2}{*}{ Growth parameters } & \multicolumn{2}{|c|}{ High-school } & \multicolumn{2}{|c|}{ University } \\
\hline & boys & girls & males & females \\
\hline Height, cm & $175.5 \pm 0.4$ & $165.4 \pm 0.5^{\star}$ & $176.9 \pm 0.5$ & $165.9 \pm 0.3$ \\
\hline Body weight, kg & $65.0 \pm 1.0$ & $55.2 \pm 1.1^{*}$ & $72.4 \pm 0.9^{\star \star}$ & $58.7 \pm 0.7^{\star \star}$ \\
\hline Fat mass, kg & $10.1 \pm 0.2$ & $13.0 \pm 0.1^{*}$ & $13.9 \pm 0.2^{\star \star}$ & $15.9 \pm 0.3^{\star \star}$ \\
\hline Recommended fat mass reduction/increase, $\mathrm{kg}$ & $0.2 \pm 0.01$ & $0.2 \pm 0.01$ & $-2.5 \pm 0.05$ & $-2.4 \pm 0.04$ \\
\hline Muscle mass, kg & $30.1 \pm 0.7$ & $22.9 \pm 0.8^{\star}$ & $33.0 \pm 0.5$ & $23.3 \pm 0.7$ \\
\hline Recommended muscle mass reduction/increase & $3.7 \pm 0.7$ & $3.9 \pm 0.6$ & $1.8 \pm 0.4$ & $3.6 \pm 0.5$ \\
\hline
\end{tabular}

Note: * $p<0.05$ - between high-school boys and girls; ${ }^{* *} p<0.05$ between high-school and university students.

Table 3. Relative risks of deviations from normal growth patterns in high-school and university students based on the frequency of exposure to stationary ED

\begin{tabular}{|c|c|c|c|c|c|}
\hline Outcomes & Factor & RR (relative risk) & EF, \% (etiologic fraction) & Se (sensitivity of the method) & Sp (specificity of the method) \\
\hline $\begin{array}{c}\text { Body weight } \\
\text { deficit }\end{array}$ & $\begin{array}{c}\text { Frequency of exposure } \\
\text { to stationary ED (every day) }\end{array}$ & 2.13 & 23.6 & 0.29 \\
\hline $\begin{array}{c}\text { Excess body } \\
\text { weight }\end{array}$ & $\begin{array}{c}\text { Frequency of exposure } \\
\text { to stationary ED (every day) }\end{array}$ & 1.59 & 9.8 & 0.88 \\
\hline
\end{tabular}


The participants used at least 2 different types of ED every day, such as a mobile phone and a stationary computer or a laptop, in the first place (Pearson's correlation coefficient was $0.5 ; p<0.001)$.

The participants switched from their mobile phones to ED and back throughout the day, which means that total daily screen time was prolonged. For high-school students, total daily screen time (inside and outside the classroom) was $7 \mathrm{~h}$. For male university students, it was $8.5 \mathrm{~h}$ and for female students, $10 \mathrm{~h}$. The observed trends did not differ between the regions.

Lastly, we investigated the impact of frequent (daily) and prolonged (in terms of hours) use of ED on the physical growth of the participants and its contribution to developing weight deficit or excess weight.

The risks were analyzed. Knowing the risk factors and their significance will help in developing methods for risk mitigation and prevention of adverse effects on young people's health (Table 3).

For body weight deficit, RR was 2.13 (DI: 2,01-2,21), i.e., daily exposure to stationary ED increases the risk of body weight deficit and contributes to negative outcomes. The etiologic fraction was as high as almost 24\%; apparently, other factors made their contribution, too.

For excess body weight, RR was 1.59 (DI: 1.11-3.15); the etiologic fraction was $9.8 \%$.
With mobile ED and a different frequency of weekly exposure to $\mathrm{ED}$, no risks were identified. Perhaps, exposure to stationary ED leads to the reduction of physically active behaviors, thereby affecting the growth and development of a child.

However, the analysis of correlations between fat mass and the duration of exposure to either stationary or mobile ED expressed in hours reveals statistically significant $(p<0.05)$ correlations between fat mass and the duration of exposure to a computer or a laptop (0.45) and a mobile phone (0.55). Perhaps, the opportunity to use mobile phones in a sitting position in wi-fi zones in public transport, shopping malls, and parks turns the phone into a stationary device.

We also determined the total daily exposure time to stationary and mobile ED that did not have a negative impact of young people's health (Fig. 1-2).

The analysis reveals that safe daily screen time is below 3 hours a day. Considering that there are always children, adolescents and young people in a population whose physical development is not harmonious, a $5.0 \%$ body weight gain (relative to the reference values) ensuing from 4 hours of daily exposure to ED would be acceptable if 4 hours of screen time a day were not correlated with a sharp increase in body weight deficit (up to $21.0 \%$ ).

We also analyzed the correlations between the abnormalities in physical growth of high-school students with different body

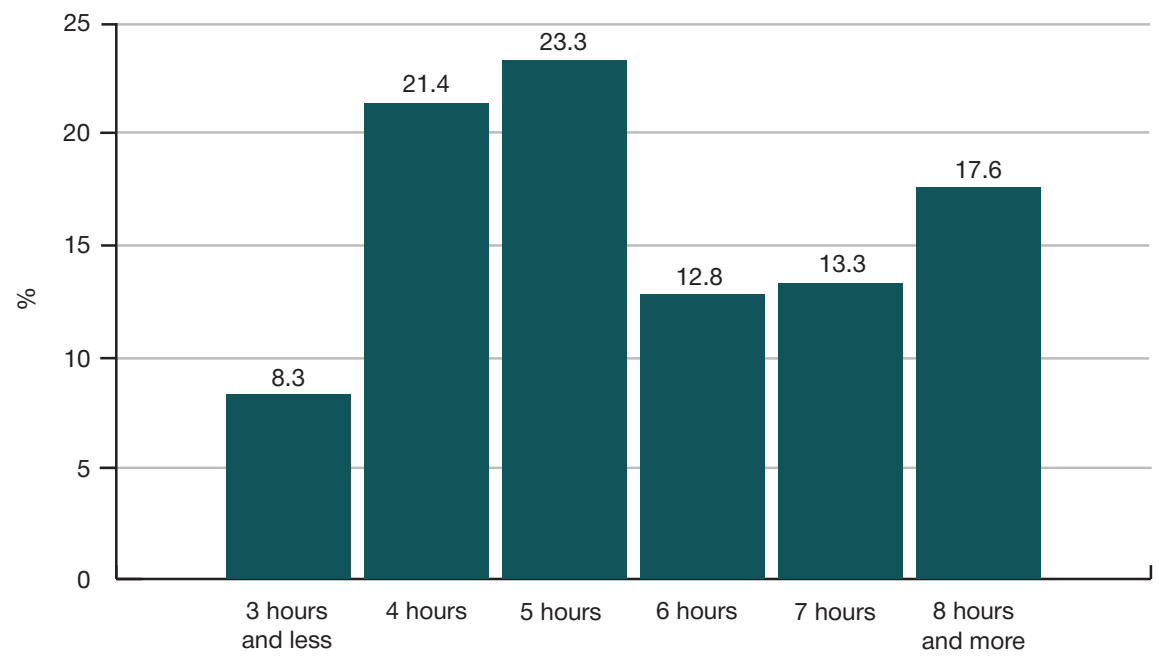

Fig. 1. Body weight deficit in high-school and university students exposed to different amounts of screen time a day

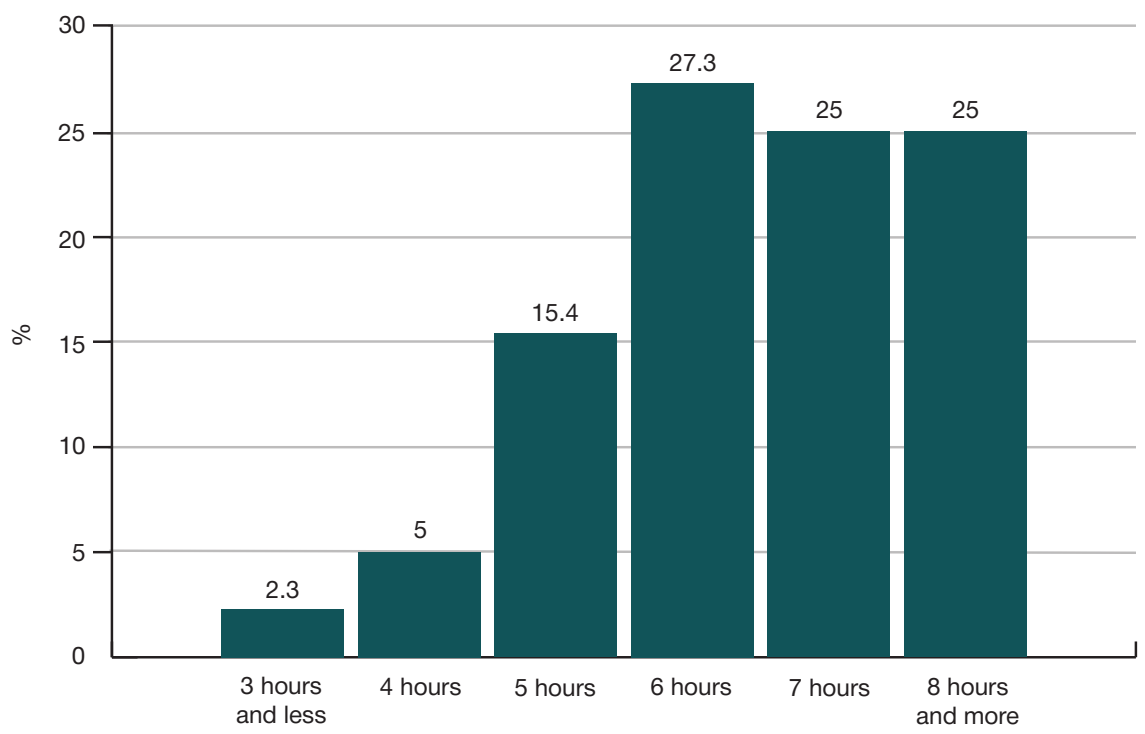

Fig. 2. Excess body weight in high-school and university students exposed to different amounts of screen time a day 
builds and the frequency of weekly exposure to stationary ED (a computer or a laptop).

Body weight deficit was observed only in asthenic children (100\%) from the subgroup of individuals who used ED once or twice a week. Exposure to ED 3 to 4 times a week was associated with body weight deficit in both asthenic (80\%) and muscular (20\%) types. Regular daily exposure to ED affected asthenic (60\%), muscular (20\%) and thoracic (20\%) types. We conclude that it is not only "weak" types who can develop body weight deficit, which they are prone to, but also "strong" muscular types, who usually do not have this propensity.

Excess weight was observed in the children with abdominal body build (100\%) who used ED once or twice a week. Exposure to ED 3 to 4 times a week was associated with excess weight in abdominal (75\%) and thoracic (25\%) types. Regular daily exposure to ED affected abdominal (50\%), thoracic (25\%) and muscular $(25 \%)$ types. We conclude that the "weak" thoracic type usually not prone to accumulating fat can develop excess body weight associated with exposure to ED.

Besides, after frequent and prolonged exposure to a combination of stationary and mobile ED, high-school and university students complained of fatigue (26\% and $58 \%$, respectively). Prolonged screen time also triggered anxiety. University students who used ED over 5 hours a day had a high level of anxiety (48.2 \pm 2.6 points on the anxiety scale); students who used ED 3 to 5 hours a day scored $42.1 \pm$ 1.6 points (moderate anxiety) and those who used ED 1 to 3 hours a day scored $36.1 \pm 1.2$ points (moderate anxiety). The analysis revealed statistically significant correlations between anxiety and the duration of exposure to ED expressed in hours $(r=0.66 ; p<0.05)$

\section{DISCUSSION}

In a population, there are always children, adolescents and young people whose physical development is not harmonious. In the last decade, the number of Moscow residents with excess weight and weight deficit in the age group of 8 to 17 years has risen to $11.5 \%$ and $22.3 \%$, respectively, which is consistent with the reports of other researchers $[22,23]$.

Our findings demonstrate that this trend is gaining momentum. Only $60 \%$ of the participants could boast harmonious physical development. This was not determined by their place of residence or the type of educational institution they were attending. According to the population studies conducted before ED became omnipresent, at that time 68\% of the population were developing normally [22]. The negative trend we observed prompts investigation of ED contribution to body weight deficit and excess weight in young people.

Frequent and prolonged exposure to ED significantly changes the lifestyle of modern students, stealing time allocated for sleep and physical activities [24, 25].

Overuse of ED and obsession with modern ICT has a profound impact on the wellbeing of children and university students, increasing anxiety, causing sleep problems and other health problems $[26,27]$.

\section{References}

1. Buhtijarov IV, Denisov JI, Eremin AL. Osnovy informacionnoj gigieny: koncepcii i problemy innovacii. Gigiena i sanitarija. 2014; 93 (4): 5-9. Russian.

2. Kuchma VR, Suhareva LM, Hramcov PI. Gigienicheskaja
In this study, we were able to assess the impact of ED on the physical development of young people. The study demonstrates that daily exposure to stationary ED increases the risk of inharmonious physical development caused by weight deficit or excess weight gain by $24 \%$ and $10 \%$, respectively. Because no risks were identified associated with a different frequency of exposure to stationary ED, we believe that introducing at least one ED-free day into a weekly schedule is a good safety measure that will also give a student more spare time for physical activities.

The fact that the use of stationary ED once or twice a week promotes body weight deficit only in asthenic children and excess weight gain only in the abdominal type speaks in favor of our proposal. At the same time, regular daily use of stationary ED can cause health problems in any body build type.

The study demonstrates that the impact of ED on highschool and university students should be assessed in the context of its total duration, meaning that we should account for both classroom and recreational screen time and the use of both stationary and mobile ED. Reducing total screen time to 3 hours a day would be an effective measure for preventing body weight deficit or excess weight gain. However, one should bear in mind that young people tend to respond negatively to strict measures, so positive health promotion should also be included in to the equation [28-30].

Because it takes a certain time for the body size and composition to change, we additionally assessed the impact of ED on more labile psychoemotional parameters. We found that university students who use stationary and mobile ED below 3 hours a day have a lower level of anxiety.

Sedentary behaviors associated with ED result in the lack of physical activities, which is key to understanding the results yielded by the study. Its deficit prevents muscle mass from developing and promotes fat deposition. The effects of frequent and prolonged use of ED can be presented as the following chain of events: frequent and prolonged exposure to ED $\rightarrow$ prevailing sedentary behaviors $\rightarrow$ reduction in physical activity $\rightarrow$ reduced muscle mass and growing fat mass $\rightarrow$ deviation from normal physical development and growth.

Our study does not cover the whole range of possible consequences of frequent and prolonged exposure to ED. For example, we have not investigated the effect of ED on muscle strength and lung capacity in young people.

\section{CONCLUSIONS}

Frequent and prolonged use of ED by young people is one of the factors that could interfere with their normal growth and physical development. This factor however, can be controlled. Safety measures include total elimination of a computer or laptop from daily activities at least once a week (at the weekend) and reduction of total screen time to 3 hours a day. It is also important to promote healthy lifestyles, educate young people about the consequences of ED overuse and their role in health problems, including obesity. 
vozdejstvija impul'sov jelektromagnitnyh polej. Jekologija cheloveka. 2018; (1): 3-7. Russian.

4. Denisov JI. Informacionnaja gigiena i regulirovanie informacii dlja ujazvimyh grupp naselenija. Gigiena i sanitarija. 2014; 93 (5): 43-9. Russian.

5. Vjatleva OA, Kurganskij AM. Mobil'nye telefony i zdorov'e detej 6-10 let: znachenie vremennyh rezhimov i intensivnost' izluchenija. Zdorov'e naselenija i sreda obitanija. 2017; 8 (293): 27-30. Russian.

6. Popov $\mathrm{VI}$, Melihova EP. Izuchenie i metodologija issledovanija kachestva zhizni studentov. Gigiena i sanitarija. 2016; 95 (9): 87984. Russian.

7. Vershinin AE, Avdonina LA. Vlijanie sotovyh telefonov na zdorov'e cheloveka. Vestnik Penzenskogo gosudarstvennogo universiteta. 2015; 3 (11): 175-7. Russian.

8. Vasileva TI, Sarokvasha OJ. Vlijanie jelektromagnitnogo polja sotovogo telefona na organizm cheloveka $v$ zavisimosti ot vozrasta. Vestnik Samarskogo gosudarstvennogo universiteta. 2012; 3/2 (94): 29-36. Russian.

9. Kazarjan KR, Plugotarenko SA, Vorob'eva EN, Davydov SG, Levova IJu, Ishunkina IV, i dr. Internet v Rossii v 2017. Sostojanie, tendencii i perspektivy razvitija. Otraslevoj doklad. M.: Tipografija «Forvard Print», 2018; 96 s. Russian.

10. Vyatleva OA. Mobil'nye telefony i zdorov'e detej $6-10$ let: znachenie vremennyh rezhimov i intensivnost' izluchenija. Zdorov'e naselenija i sreda obitanija. 2017; 8 (293): 27-30. Russian.

11. Kuchma VR, Suhareva LM, Hramcov PI. Covremennye podhody k obespecheniju gigienicheskoj bezopasnosti zhiznedejatel'nosti detej $\vee$ giperinformacionnom obshhestve. Voprosy shkol'noj i universitetskoj mediciny i zdorov'ja. 2015; (3): 22-7. Russian.

12. Sokolova NV, Popov VI, Alferova SI, Artjuhova IG, Kvarachelija AG. Kompleksnyj podhod $\mathrm{k}$ gigienicheskoj ocenke kachestva zhizni studencheskoj molodezhi. Bjulleten' Vostochno-Sibirskogo nauchnogo centra Sibirskogo otdelenija Rossijskoj akademi medicinskih nauk. 2013; 3-2 (91): 130-4. Russian.

13. Wimalasundera S. Computer vision syndrome. Galle Medical. 2006; 11 (1): 201-4.

14. Lepp A, Barcley JE, Karpinski AC. The relationship between cell phone use, academic performance, anxiety, and Satisfaction with Life in college students. Computers in Human Behavior. 2014; (31): 343-50.

15. Lanaj $\mathrm{K}$, Johnson RE, Barnes CM Beginning the workday yet already depleted? Consequences of late-night smartphone use and sleep. Organizational Behavior and Human Decision Processes. 2014; 124 (1): 11-23.

16. Kuchma VR, Tkachuk EA, Tarmaeva IJu. Psihofiziologicheskoe sostojanie detej $v$ uslovijah informatizacii in zhiznedejatel'nosti i intensifikacii obrazovanija. Gigiena i sanitarija. 2016; 95 (12): 1183-8. Russian.

17. Koncepciya informacionnoj bezopasnosti detej. Rasporjazhenie pravitel'stva RF № 2471-r (02 dekabrja 2015). Russian.

18. Baranov AA, Kuchma VR, Skoblina NA. Fizicheskoe razvitie detej na rubezhe tysjacheletij. M.: NCZD RAMN, 2008; 216 s. Russian.

19. Kuchma VR, Ushakov IB, Sokolova NV, Rapoport IK, Esaulenko IJe, Gubina OI, i dr. Metody ocenki kachestva zhizni shkol'nikov. Voronezh: Istoki, 2006; 112 s. Russian.

20. Kuchma VR, Suhareva LM, Hramcov PI, Rapoport IK, Zvezdina IV, Sokolova SB, i dr. Rukovodstvo po gigiene detej i podrostkov, medicinskomu obespecheniju obuchajushhihsja v obrazovatel'nyh organizacijah. M.: Izd-vo NCZD RAMN, 2016; 610 s. Russian.

21. Medicinskaya statistika: onlajn kal'kuljatory dlja rascheta statisticheskih kriteriev. Dostupno po ssylke: https://medstatistic. ru/calculators.html.

22. Milushkina OJ. Markelova SV, Skoblina NA, Tatarinchik AA, Fedotov DM, Korolik VV, i dr. Osobennosti obraza zhizni sovremennoj studencheskoj molodezhi. Zdorov'e naselenija i sreda obitanija. 2018; 11 (308): 5-8. Russian.

23. Kordenko AN, Kovylova VI, Popov VI, Tarasenko PA. Kriticheskie faktory kachestva zhizni podrostkov. Gigiena i sanitarija. 2015; 94 (9): 20-1. Russian.

24. Bokareva NA. Vedushhie faktory, formirujushhie fizicheskoe razvitie sovremennyh detej megapolisa Moskvy [dissertacija]. M., 2014. Russian.

25. Kuchma VR, Suhareva LM, Rapoport IK. Populjacionnoe zdorov'e detskogo naselenija, riski zdorov'ju i sanitarnojepidemiologicheskoe blagopoluchie obuchajushhihsja: problemy, puti reshenija, tehnologii dejatel'nosti. Gigiena i sanitarija. 2017; 96 (10): 990-5. Russian.

26. Ushakov IB, Popov VI, Petrova TN, Esaulenko IJ. Izuchenie zdorov'ja studentov kak rezul'tat vzaimodejstvija medikobiologicheskih, jekologicheskih i social'no-gigienicheskih faktorov riska. Medicina truda i promyshlennaja jekologija. 2017; (4): 33-6. Russian.

27. Libina II, Mazurenko NJ. Ispol'zovanie sovremennyh informacionnyh tehnologij $\vee$ gigienicheskom obuchenii studentov medicinskogo vuza. Prikladnye informacionnye aspekty mediciny. 2016; 19 (4): 39-42. Russian.

28. Kuchma VR, Milushkina OJ, Bokareva NA, Skoblina NA Sovremennye napravlenija profilakticheskoj raboty $v$ obrazovatel'nyh organizacijah. Gigiena i sanitarija. 2014; 93 (6): 107-11. Russian.

29. Baranov AA, Kuchma VR, Anufrieva EV, Sokolova SB, Skoblina NA, Virabova AR. i dr. Ocenka kachestva okazanija medicinskoj pomoshhi obuchajushhimsja $v$ obrazovatel'nyh organizacijah. Vestnik Rossijskoj akademii medicinskih nauk. 2017; 72 (3): 18094. Russian.

30. Sokolova NV, Popov VI, Kartysheva SI, Koroleva AO. Nekotorye aspekty profilakticheskoj dejatel'nosti uchitelja, napravlennoj na uluchshenie sostojanija zdorov'ja shkol'nikov. Gigiena i sanitarija. 2014; 93 (1): 90-1. Russian.

\section{Литература}

1. Бухтияров И. В., Денисов Э. И., Еремин А. Л. Основы информационной гигиены: концепции и проблемы инноваций. Гигиена и санитария. 2014; 93 (4): 5-9.

2. Кучма В. Р., Сухарева Л. М., Храмцов П. И. Гигиеническая безопасность жизнедеятельности детей в цисровой среде. Здоровье населения и среда обитания. 2016; 8 (281): 4-7.

3. Ушаков И. Б., Попов В. И., Попова О. А. Некоторые аспекты экологической безопасности человека в условиях хронического воздействия импульсов электромагнитных полей. Экология человека. 2018; (1): 3-7.

4. Денисов Э. И. Информационная гигиена и регулирование информации для уязвимых групп населения. Гигиена и санитария. 2014; 93 (5): 43-9.

5. Вятлева О. А., Курганский А. М. Мобильные телефоны и здоровье детей 6-10 лет: значение временных режимов и интенсивность излучения. Здоровье населения и среда обитания. 2017; 8 (293): 27-30.

6. Попов В. И., Мелихова Е. П. Изучение и методология исследования качества жизни студентов. Гигиена и санитария.

2016; 95 (9): 879-84.

7. Вершинин А. Е., Авдонина Л. А. Влияние сотовых телесонов на здоровье человека. Вестник Пензенского государственного университета. 2015; 3 (11): 175-7.

8. Васильева Т. И., Сарокваша О. Ю. Влияние электромагнитного поля сотового телефона на организм человека в зависимости от возраста. Вестник Самарского государственного университета. 2012; 3/2 (94): 29-36.

9. Казарян К. Р., Плуготаренко С. А., Воробьева Е. Н., Давыдов С. Г., Левова И. Ю., Ишунькина И. В. и др. Интернет в России в 2017. Состояние, тенденции и перспективы развития. Отраслевой доклад. М.: Типограсиия «Форвард Принт», 2018; 96 с.

10. Вятлева, О. А. Мобильные телефоны и здоровье детей 6-10 лет: значение временных режимов и интенсивность излучения. Здоровье населения и среда обитания. 2017; 8 (293): 27-30.

11. Кучма В. Р., Сухарева Л. М., Храмцов П. И. Современные подходы к обеспечению гигиенической безопасности жизнедеятельности детей в гиперинформационном обществе. 
Вопросы школьной и университетской медицины и здоровья. 2015; (3): 22-7.

12. Соколова Н. В., Попов В. И., Алферова С. И., Артюхова И. Г., Кварацхелия А. Г. Комплексный подход к гигиенической оценке качества жизни студенческой молодежи. Бюллетень Восточно-Сибирского научного центра Сибирского отделения Российской академии медицинских наук. 2013; 3-2 (91): 130-4.

13. Wimalasundera S. Computer vision syndrome. Galle Medical. 2006; 11 (1): 201-4.

14. Lepp A, Barcley JE, Karpinski AC. The relationship between cell phone use, academic performance, anxiety, and Satisfaction with Life in college students. Computers in Human Behavior. 2014; (31): 343-50.

15. Lanaj $\mathrm{K}$, Johnson RE, Barnes CM Beginning the workday yet already depleted? Consequences of late-night smartphone use and sleep. Organizational Behavior and Human Decision Processes. 2014; 124 (1): 11-23.

16. Кучма В. Р., ТкачукЕ. А., Тармаева И. Ю. Психосизиологическое состояние детей в условиях информатизации их жизнедеятельности и интенсификации образования. Гигиена и санитария. 2016; 95 (12): 1183-8.

17. Концепция инсормационной безопасности детей. Распоряжение правительства РФ № 2471-р (02 декабря 2015). Доступно по ссылке: http://www.consultant.ru/document/cons_ doc_LAW_190009/.

18. Баранов А. А., Кучма В. Р., Скоблина Н. А. Физическое развитие детей на рубеже тысячелетий. М.: НЦЗД РАМН, 2008; 216 c.

19. Кучма В. Р., Ушаков И. Б. и др. Методы оценки качества жизни школьников. Воронеж: Истоки, 2006; 112 с.

20. Кучма В. Р., Сухарева Л. М., Храмцов П. И., Рапопорт И. К., Звездина И. В., Соколова С. Б. и др. Руководство по гигиене детей и подростков, медицинскому обеспечению обучающихся в образовательных организациях. М.: Изд-во НЦЗД РАМН, 2016; 610 c.

21. Медицинская статистика: онлайн-калькуляторы для расчета статистических критериев. Доступно по ссылке: https:// medstatistic.ru/calculators.html.
22. Бокарева Н. А. Ведущие факторы, формирующие физическое развитие современных детей мегаполиса Москвы [диссертация]. M., 2014.

23. Кучма В. Р., Сухарева Л. М., Рапопорт И. К. Популяционное здоровье детского населения, риски здоровью и санитарноэпидемиологическое благополучие обучающихся: проблемы, пути решения, технологии деятельности. Гигиена и санитария. 2017; 96 (10): 990-5.

24. Милушкина О. Ю. Маркелова С. В., Скоблина Н. А., Татаринчик А. А., Федотов Д. М., Королик В. В. и др. Особенности образа жизни современной студенческой молодежи. Здоровье населения и среда обитания. 2018; 11 (308): 5-8.

25. Корденко А. Н., Ковылова В. И., Попов В. И., Тарасенко П. А. Критические факторы качества жизни подростков. Гигиена и санитария. 2015; 94 (9): 20-1.

26. Ушаков И. Б., Попов В. И., Петрова Т. Н., Есауленко И. Э. Изучение здоровья студентов как результат взаимодействия медико-биологических, экологических и социальногигиенических факторов риска. Медицина труда и промышленная экология. 2017; (4): 33-6.

27. Либина И. И., Мазуренко Н. Ю. Использование современных инсормационных технологий в гигиеническом обучении студентов медицинского вуза. Прикладные информационные аспекты медицины. 2016; 19 (4): 39-42.

28. Кучма В. Р., Милушкина О. Ю., Бокарева Н. А., Скоблина Н. А. Современные направления профилактической работы в образовательных организациях. Гигиена и санитария. 2014; 93 (6): 107-11.

29. Баранов А. А., Кучма В. Р., Анусриева Е. В., Соколова С. Б., Скоблина Н. А., Вирабова А. Р. и др. Оценка качества оказания медицинской помощи обучающимся в образовательных организациях. Вестник Российской академии медицинских наук. 2017; 72 (3): 180-94.

30. Соколова Н. В., Попов В. И., Картышева С. И., Королева А. О. Некоторые аспекты профилактической деятельности учителя, направленной на улучшение состояния здоровья школьников. Гигиена и санитария. 2014; 93 (1): 90-1. 